Int. J. Electrochem. Sci., 13 (2018) 9771 - 9783

\title{
Effect of Temperature and Voltage on the Preparation of Solid Carbon by Electrolysis of a Molten $\mathrm{CaCO}_{3}-\mathrm{Li}_{2} \mathrm{CO}_{3}-\mathrm{LiCl}$ Electrolyte
}

\author{
Karen Wong Min Jin ${ }^{1}$, Miron Gakim ${ }^{1}$, Jidon A. Janaun ${ }^{2}$, Willey Liew Y. H. ${ }^{1}$, Nancy J. Siambun ${ }^{1,3, *}$ \\ ${ }^{1}$ Mechanical Engineering Programme, Faculty of Engineering, Universiti Malaysia Sabah, Jalan UMS \\ 88400 Kota Kinabalu, Sabah, Malaysia \\ ${ }^{2}$ Chemical Engineering Programme, Faculty of Engineering, Universiti Malaysia Sabah, Jalan UMS \\ 88400 Kota Kinabalu, Sabah, Malaysia \\ ${ }^{3}$ Material and Mineral Research Unit, Faculty of Engineering, Universiti Malaysia Sabah, Jalan UMS \\ 88400 Kota Kinabalu, Sabah, Malaysia \\ *E-mail: nancyjs@ums.edu.my
}

doi: $10.20964 / 2018.10 .43$

Received: 22 April 2018 / Accepted: 12 June 2018 / Published: 1 September 2018

The present study investigated the preparation of solid carbon through the electrolysis of a newly formulated molten salt electrolyte containing $\mathrm{CaCO}_{3}-\mathrm{Li}_{2} \mathrm{CO}_{3}-\mathrm{LiCl}$ with a continuous cell voltage of $4-6 \mathrm{~V}$, and temperatures of 550 and $650^{\circ} \mathrm{C}$. The process was carried out in a two-electrode cell using AISI 304 stainless steel electrodes in $\mathrm{CO}_{2}$ gas environment. $\mathrm{CO}_{2}$ gas was captured and electro-converted to solid carbon, and deposited on the cathode surface. SEM images revealed five dominant microstructures: grape-like, tubes, thread-like, spheres, and flakes. These materials consist of $69-80 \%$ carbon content based on EA analysis. Single wall nanotube structures of $13-90 \mathrm{~nm}$ outer diameter was also detected under TEM analysis. The result revealed that electrolysis voltage and temperature changes affected the microstructures, quantity of the deposited carbon, and the efficiency of electro-conversion process. The size of the carbon microstructures declined, and carbon deposition rate increased as both voltage and temperature were increased. However, it reduced the efficiency of the process, thus using more energy per $g$ of carbon produced.

Keywords: Carbon, electro-deposition, electrolysis, molten salts, effect, temperature, voltage.

\section{$\underline{\text { FULL TEXT }}$}

(C) 2018 The Authors. Published by ESG (www.electrochemsci.org). This article is an open access article distributed under the terms and conditions of the Creative Commons Attribution license (http://creativecommons.org/licenses/by/4.0/). 